九州大学学術情報リポジトリ

Kyushu University Institutional Repository

\title{
DESCRIPTIONS OF TWO NEW SPECIES OF THE FAMILY BRENTIDAE FROM JAPAN (COLEOPTERA)
}

Morimoto, Katsura

Entomological Laboratory, Faculty of Agriculture, Kyushu University

https://doi.org/10.5109/2388

出版情報 : ESAKIA. 14，pp. 25-30，1979-11-15. Entomological Laboratory，Faculty of Agriculture， Kyushu University

バージョン :

権利関係 : 


\title{
DESCRIPTIONS OF TWO NEW SPECIES OF THE FAMILY BRENTIDAE FROM JAPAN (COLEOPTERA)*
}

\author{
KATSURA Morimoto \\ Entomological Laboratory, Faculty of Agriculture \\ Kyushu University, Fukuoka 812, Japan
}

\begin{abstract}
Two new species of the family Brentidae are described from Japan. They are Callipareius (Callipareius) miyakawai and Baryrhynchus yaeyamensis; the latter was once mistaken for miles Boheman by the author (1976).
\end{abstract}

The following descriptions are addition and correction to the author's "Japanese species of the family Brentidae" appeared in Kontŷ̂, 44: 267-282, 1976.

The author wishes to express his sincere thanks to Prof. Y. Hirashima for his encouragement in the course of the present study. Thanks are also due to Dr. S. Kimoto and Messrs. M. T. Châjô, T. Hatayama, 'H. Irie, M. Kina, H. Makihara, T. Mikage, S. Miyakawa and K. Sugino for their kindness giving him the materials for study.

Callipareius (Callipareius) miyakawai sp. nov. (Fig. 1)

Male: Rostrum, dorsal surface of head, pronotum except for black lateral margins, three or four basal and terminal segments of antennae, tibiae and tarsi reddish brown; antennae from four or five to penultimate segment dark reddish brown ; under- and lateral sides of body black; femora blackish brown with reddish brown bases and apices; elytra with dark brown to blackish stripes on lst, 2nd, 4th,7th, 9th and 10th intervals, 3rd, 5th and 8 th intervals brownish yellow, 3rd interval with a dark brown short spot a little behind base, declivity and apices reddish brown.

Head as long as wide, weakly rounded and narrowed behind ; vertex weakly convex, glossy, sparsely with fine punctures, interstices between punctures much broader than the diameter; frons between eyes with a fine median sulcus, which continued anteriorly to the median sulcus on metarostrum; eyes small, lateral. Rostrum a little narrower than head; metarostrum on the same

* Contribution from the Entomological Laboratory, Faculty of Agriculture, Kyushu University, Fukuoka (Ser. 3, No. 61). 


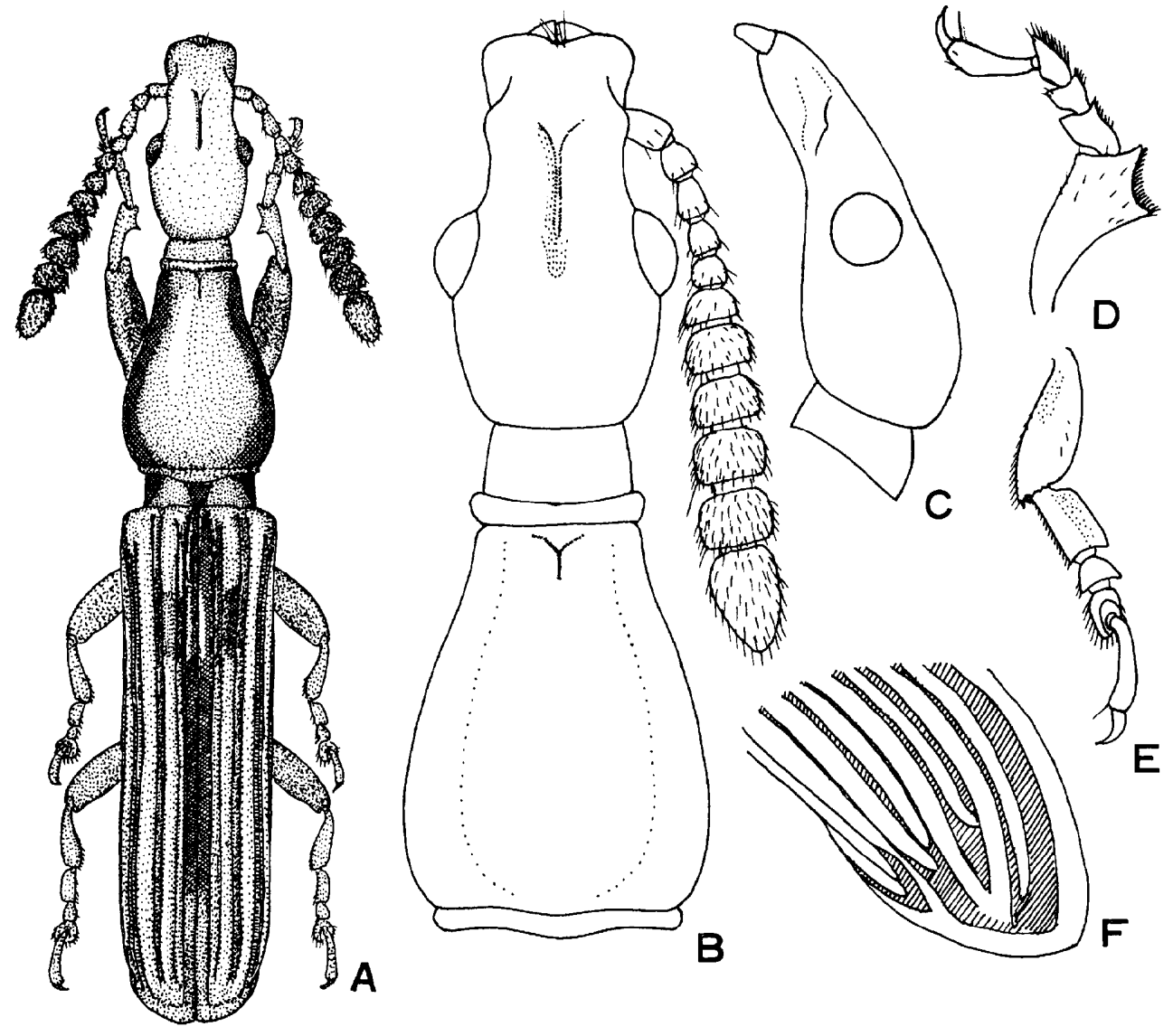

Fig. 1. Callipareius (Callipareius) miyakawai sp. nov., male. A, B: Holotype. C: Head, lateral aspect. D: Front leg. E: Hind leg. F : Apex of left elytron.

plane as frons, with a deep median sulcus, similarly punctate as on frons; prorostrum slightly inclined anteriorly, intricately aciculate, triangularly emarginate at apex, with small indistinct punctures. Antennae robust, 2nd segment conical, a little broader than long, 3rd segment conical, a little longer than wide, 4th segment nearly the same as 2nd in shape, 5th to 10th segments transverse, terminal segment 1.5 times as long as wide. Underside of head finely intricately aciculate, with sparse fine punctures, with a deep median fovea just before the constriction of head and a broad shallow depression on rostrum.

Pronotum pyriform, longer than wide $(4: 3)$, disc very sparsely with fine punctures, with a very short median sulcus behind subapical constriction.

Elytra slender, 2.3-2.4 times as long as pronotum, 1st, 3rd, 5th and 8th intervals broader, with fine punctures, the other intervals narrower and as 
wide as striae, 3rd and 5th intervals costate on declivity, 8th interval costate behind and connate to posterior margin.

Prosternum before coxae transversely and finely wrinkled, mesepisternum strongly punctate, metasternum convex with lateral depressions for the reception of middle femora, metepisternum linear, with a row of punctures along metepisternal suture behind the middle. Venter with the 1st segment depressed along posterior margin of coxae, 1st and 2nd segments with lateral depressions for the reception of hind femora, 2nd to 4th segments each transversely depressed along the posterior margin, 1st and 2nd segments almost impunctate, 3rd and 4th segments sparsely punctate, 5th segment closely with setigerous punctures,

Femora strongly compressed dorsally at base. Fore tibiae with sharp ventral, anterior and inner points, the inner point triangular and with setose fringe between the inner and the anterior points. Middle and hind tarsi longer than front one with compressed 1st segment.

Female: Rostrum a little slenderer; 5th segment of abdomen gently rounded posteriorly, with close setigerous punctures on apical half.

Length :4.4-8. $0 \mathrm{~mm}$ (incl. rostrum).

Holo type (Type No. 2150, Kyushu Univ.), Ako Rindo, Is. Miyakejima, Izu Shichito Isls., 3. v. 1978, J. Okuma leg.

Paratypes:131 , same data as holotype,1年, same locality as holotype, 27. iv. 1978, J. Okuma leg. 1 ㅇ, Nanto Rindo, Is. Miyakejima, 3. v. 1978, J. Okuma leg.

Distribution : Japan (Izu Shichito Isls.: Miyakejima).

This new species is close to lineatosignatus (Kleine, 1939) from Burma, but the coloration of rostrum, head and pronotum is different.

Name of this interesting new species is dedicated to Mr. Sumiaki Miyakawa, who kindly entrusted the specimens to the author for study.

Baryrhynchus yaeyamensis sp. nov. (Figs. 2, 3)

Baryrhynchus miles, Morimoto (nec Boheman), Kontyû, 44: 278, 1976.

Male: Blackish brown to black, head, rostrum, antennae, legs and prosternum reddish brown to dark reddish brown; elytra with yellowish orange to reddish brown patches, the basal patches on 3rd and 5th intervals, the latter small, the antemedian patches on 4 th, 5-6th, 8-9th and frequently on 7 th intervals, the patch on 4th interval often extends over 3rd interval, the postmedian patches on 3rd to 6th intervals and often small patches on 2nd and 7th intervals; the subapical patches on 3rd and 9th intervals and a small patch at the joint of 4 th and 6th intervals.

Head conical; vertex weakly convex, sparsely with fine punctures, median sulcus fine. Rostrum narrowed from base to antenna1 sockets and widening laterally on prorostrum; disc with a wide depression surrounded laterally by 


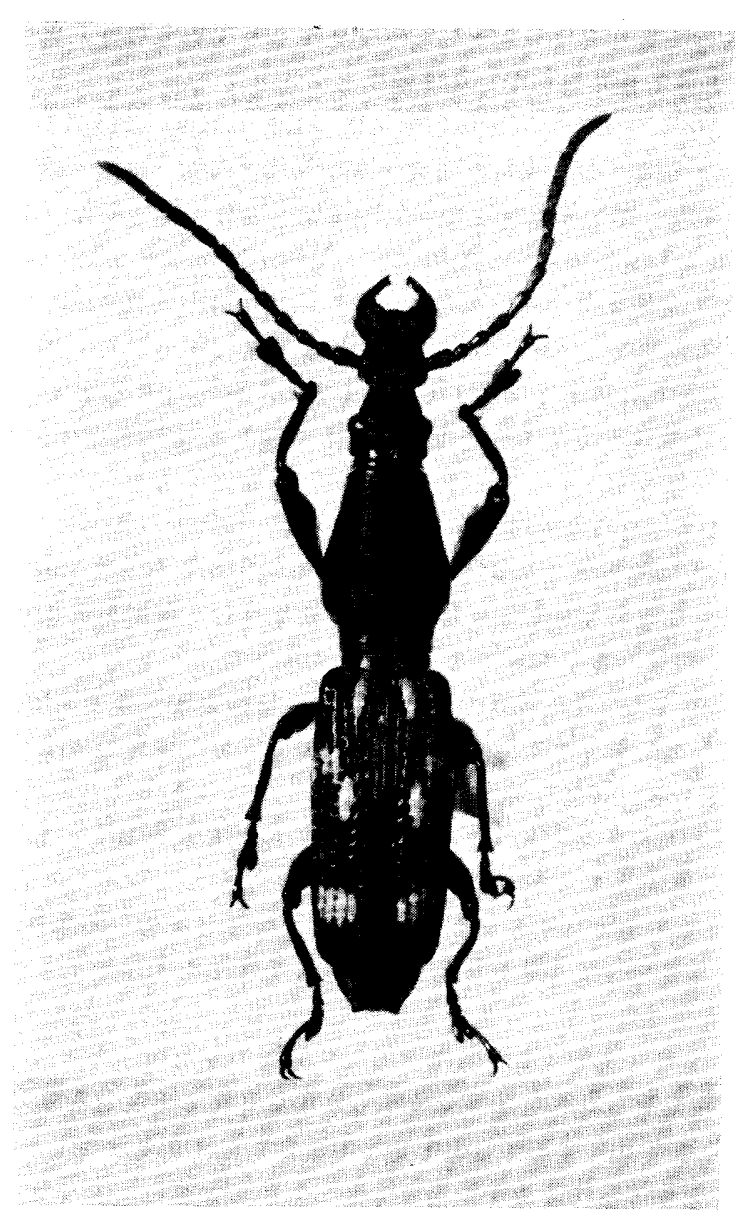

Fig. 2. Baryrhynchus yaeyamensis sp. nov., male.

obtuse keels on the anterior half of metarostrum and prorostrum, the keels interrupted on mesorostrum and obsolete on the base of metarostrum and head, median depression divided by a transverse keel on mesorostrum, anterior margin between mandibles bisinuate in the individuals of medium apd large size or uni-sinuate in smaller individuals; mandibles rather long and curved, intermandibular space fairly wide. Underside of rostrum with a pair of projections on metarostrum and a pyramidal process on prorostrum, more or less costate and warped ventrally on each side on pro- and mesorostrum.

Pronotum 1.3-1. 4 times as long as wide, mat, indistinctly wrinkled and very sparsely punctulate, sparsely hairy on margins, the hairs on anterior margin a little longer and bifurcate, those on basal area just before the basal constriction a little denser and usually trifurcate.

Elytra glossy, parallel-sided or gently and slightly narrowing posteriorly, 

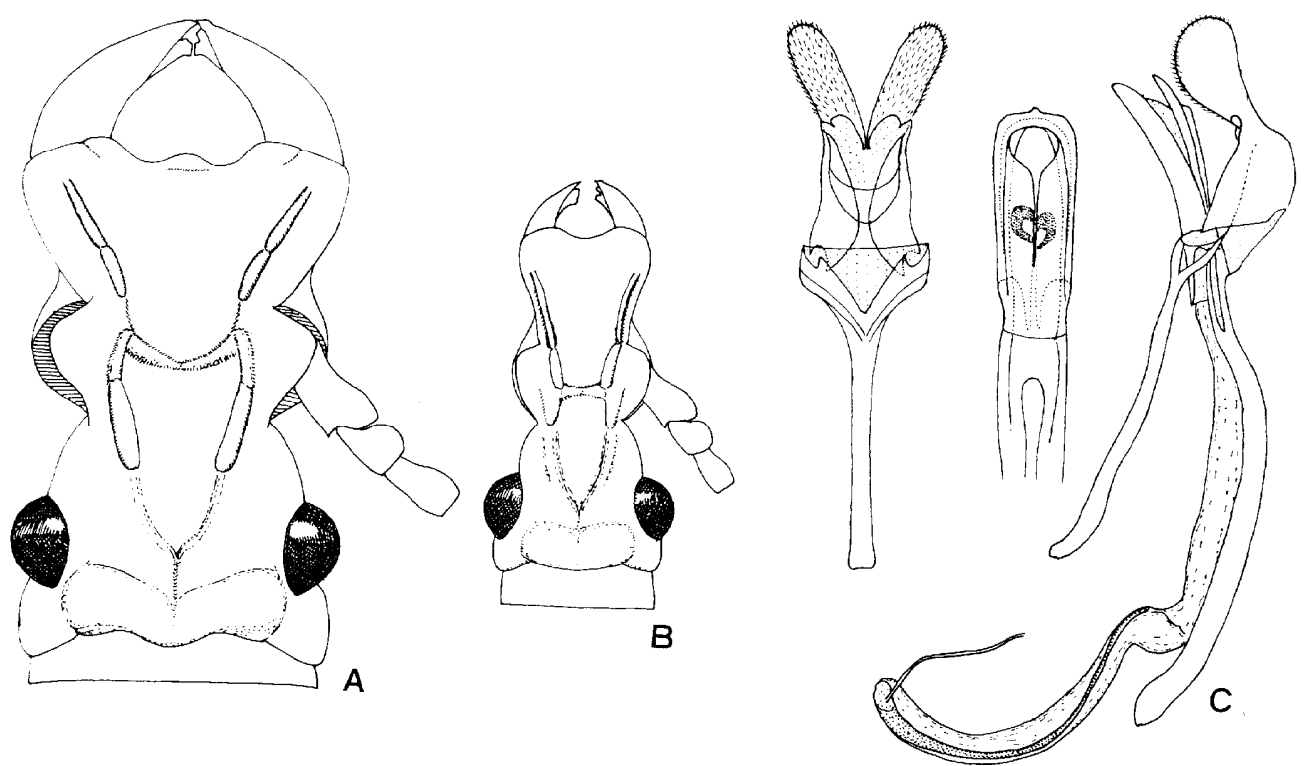

Fig. 3. Baryrhynchus yaeyamensis sp. n ov. A, B: Male head (A: Body length to the apex of rostrum $24 \mathrm{~mm}$. B: Ditto, $17 \mathrm{~mm})$. C: Aedeagus.

apicolateral angles triangularly pointed, strongly punctate-striate, intervals a little wider at the areas of reddish patches, 1st interval flat, 2nd interval narrow.

Prosternum smooth, meso- and metasternum sparsely with setigerous punctures, which are denser on each side of the median fovea at the base, lateral pieces of mesothorax with several strong punctures, metepisternum longitudinally depressed along dorsal margin. Venter sulcate along coxal margins, 1st and 2nd segments depressed longitudinally at middle, the suture between them deeper on each side, rather strongly punctate on each margin, 3rd to 5th segments closely setose on each side, 5th segment truncate at apex and densely punctate on the apical half.

Fore tibiae straight, with weak round expansion at the middle internally.

Female: Prorostrum cylindrical, glossy, mesorostrum with a pair of tubercles between antenna1 sockets; underside of head and metarostrum with a pair of rows of several large punctures; abdomen without median depression.

Length : 13.4-24.0 mm (incl. rostrum), 9.9-21.0 $\mathrm{mm}$ (excl. rostrum).

Holotype z (Type No. 2151, Kyushu Univ.), Mt. Omotodake, Is. Ishigaki, 20. v. 1974, H. Irie leg.

Paratypes: Same locality as holotype, 1우 19. vi. 1972, H. Irie leg.; 1 q 25. vi. 1972, H. Irie leg. $; 1 \precsim$, 14. iv. 1973, H. Irie leg.;1 1 †, 15. iv. 1973, H. Irie leg. ; 1 , 1. vi. 1973, K. Sugino leg, ; 1 오, 21. vi. 1973, K. Sugino leg. ; 8 3 5 오, 2526. iv. 1974, H. Irie leg.; 44 우, 7-8. v. 1974, H. Irie leg. ;1우, 18. v. 1974, H. 
Irie leg. ; $4 ð 3$ \&, 20-21. 1974, H. Irie leg.; $3 ð 2$, 23. v. 1974, H. Irie leg.; $5 \jmath^{\text {}}$ 3 ㅇ, 28. v. 1974, H. Irie leg.; 1 q, 30. vi. 1974, T. Mikage leg. 1 ㅇ, YoshiharaArakawa, Ishigaki, 17. v. 1974, H. Irie leg. 2 , Barabudo, Is. Ishigaki, 12. ix. 1935, T. Iwasaki leg. $2 \precsim$, Ushikumori, Is. Iriomote, $9 \&$ 11. iii. 1964, S. Kimoto and T. Shirôzu leg. $1 \%$, Shirahama, Is. Iriomote, 15. viii. 1961, M. Kina leg. $1 \lesssim 3$, Riv. Kuira, Is. Iriomote, 10-13. vi. 1973, T. Hatayama leg. 1 ㅇ, Riv. Kuira, Is. Iriomote, 18. vi. 1974, T. Mikage leg. 2̧, Mt. Komi, Is. Iriomote, 26. viii. 1962, M. Chûjồ leg. $1 る 2$ 우, Akaida, Is. Iriomote, 10. viii. 1962, M. Chûjô leg. 19, Kampira Fall, Is. Iriomote, 9. iv. 1973, H. Irie leg.

Distribution: Japan (Yaeyama Group of the Ryukyus: Ishigaki and Iriomote Isls.).

This new species is very close to miles and poweri, but separable from them by the following key.

\footnotetext{
1 : Rostrum truncate at apex, mandibles triangular --miles Boheman, andamanicus Power

1': Rostrum sinuate at apex, mandibles longer

2 : Elytra with two pairs of large reddish patches (Is. Akuseki)

tokarensis Ohbayashi et Sato

2': Elytra with basal, antemedian, postmedian and subapical patches $\ldots \ldots \ldots \ldots \ldots \ldots \ldots . . . . . . .3$

3 : Prothorax glossy; elytra with antemedian patches on 4th, 5th and 8th-9th intervals, patch on 5 th interval often obsolete, always absent on 6th interval; apicolateral angles of elytra blunt poweri Roelofs

3': Prothorax mat; elytra with antemedian patches on 4 th, 5 th-6th, 8 th-9th and frequently on 7 th intervals; apicolateral angles of elytra triangularly pointed 